\title{
ABSTRAK \\ Judul
: Pengaruh Kepuasan Nasabah Terhadap Loyalitas Nasabah KPR BTN Pada PT. Bank Tabungan Negara Tbk. Cabang Padang
}

\section{MARIA MAGDALENA,Spd. MM}

Salah satu bank umum yang terdapat di Kota Padang adalah PT. Bank Tabungan Negara Tbk. dengan salah satu produk andalan dalam penyaluran kredit adalah Kredit Kepemilikan Rumah Bank Tabungan Negara (KPR BTN). Dalam penyaluran kredit KPR BTN kepada calon nasabahnya, bentuk-bentuk penyaluran kredit inovatif dilakukan PT. Bank Tabungan Negara Tbk. Cabang Padang yaitu menjalin kerjasama dengan developer perumahan, mendatangi langsung calon nasabah, mempercepat proses realisasi kredit, dan melakukan penagihan pembayaran angsuran kredit jika nasabah tidak bisa datang ke bank dengan tujuan dapat memberikan kepuasan kepada nasabah KPR BTN. Nasabah KPR BTN yang telah merasakan kepuasan selanjutnya akan bersifat loyal terhadap PT. Bank Tabungan Negara Tbk. Cabang Padang.

Sesuai dengan latar belakang penelitian yang telah dikemukakan, penulis mengemukakan permasalahan yang diteliti yaitu bagaimanakah pengaruh kepuasan nasabah KPR BTN terhadap loyalitas pada PT. Bank Tabungan Negara Tbk. Cabang Padang. Untuk menjawab perumusan masalah tersebut maka digunakan nasabah KPR BTN pada PT. Bank Tabungan Negara, Tbk. Cabang Padang dengan jumlah sampel sebanyak 390 orang. Sampel penelitian diminta untuk menjawab angket penelitian yang selanjutnya digunakan sebagai data primer untuk bahan penganalisaan yang dilakukan dengan menggunakan uji validitas, uji reliabilitas, analisis persamaan regresi linier sederhana, analisis koefisien korelasi, analisis koefisien determinasi dan uji t.

Dari hasil penelitian dan penganalisaan data yang telah dilakukan maka dapatlah diketahui kepuasan nasabah KPR BTN berpengaruh positif terhadap loyalitas pada PT. Bank Tabungan Negara Tbk. Cabang Padang. Hal ini dibuktikan dengan didapatnya nilai koefisien regresi kepuasan nasabah KPR BTN bernilai positif yaitu 0,893 yaitu setiap peningkatan kepuasan nasabah KPR BTN sebesar 1 satuan akan mengakibatkan peningkatan loyalitas nasabah KPR BTN sebesar 0,893 satuan dengan asumsi variabel selain kepuasan nasabah KPR BTN adalah tetap atau tidak mengalami perubahan. Besarnya pengaruh kepuasan nasabah KPR BTN terhadap loyalitas pada PT. Bank Tabungan Negara Tbk. Cabang Padang adalah $73,2 \%$ dan sisanya 26,8\% dipengaruhi selain kepuasan nasabah KPR BTN. Misalnya pengaruh dari kualitas pelayanan, citra perusahaan, kepercayaan konsumen, dan lain-lain. Kepuasan nasabah KPR BTN berpengaruh signifikan terhadap loyalitas pada PT. Bank Tabungan Negara Tbk. Cabang Padang karena nilai signifikan dari variabel kepuasan nasabah 0,000 lebih kecil dari level of significant 0,05 . 


\section{BAB I}

\section{PENDAHULUAN}

\subsection{Latar Belakang Masalah}

Bank sebagai lembaga intermediasi memiliki fungsi dan peranan sebagai perantara keuangan. Dalam peranannya, hubungan bank dengan nasabah didasarkan pada unsur saling terkait, yaitu hukum dan kepercayaan. Suatu bank dapat melakukan kegiatan dan berkembang dengan baik apabila masyarakat percaya untuk menempatkan uangnya melalui produk penghimpunan dana yang ada pada bank tersebut. Berdasarkan kepercayaan masyarakat itulah bank menghimpun dana dari masyarakat dan menyalurkannya kembali ke masyarakat dalam bentuk kredit. Sehingga dana yang dititipkan masyarakat ke bank kemudian digunakan bank untuk kegiatan usahanya dalam bentuk penyaluran kredit akan menjadi bisnis yang penuh resiko (Bank is a Risk Business).

Salah satu bank umum yang terdapat di Kota Padang adalah PT. Bank Tabungan Negara Tbk. dengan salah satu produk andalan dalam penyaluran kredit adalah Kredit Kepemilikan Rumah Bank Tabungan Negara (KPR BTN). Dalam penyaluran kredit KPR BTN kepada calon nasabahnya, bentuk-bentuk penyaluran kredit inovatif dilakukan PT. Bank Tabungan Negara Tbk. Cabang Padang yaitu menjalin kerjasama dengan developer perumahan, mendatangi langsung calon nasabah, mempercepat proses realisasi kredit, dan melakukan penagihan pembayaran angsuran kredit jika nasabah tidak bisa datang ke bank. Hal ini dikarenakan PT. Bank Tabungan Negara Tbk. Cabang Padang sebagai salah satu perusahaan yang bergerak di bidang jasa dapat lahir dan berkembang serta mampu bertahan karena adanya kepercayaan dari masyarakat. Hal ini menuntut PT. Bank Tabungan Negara Tbk. Cabang Padang untuk dapat memberikan pelayanan jasanya yang terbaik dan menjaga citra positif di mata masyarakat. Kepercayaan masyarakat tersebut perlu diciptakan dan ditingkatkan secara terus menerus untuk meningkatkan keloyalan nasabah terhadap bank tersebut, seperti keloyalan nasabah untuk tetap melakukan transaksi KPR BTN yang dapat memberikan pelayanan yang memuaskan.

Untuk meningkatkan jumlah nasabah KPR BTN maka pemberian kredit yang diterapkan dan kepuasan nasabah terhadap pelayanan yang diberikan akan turut mempengaruhi loyalitas nasabah untuk tetap menggunakan KPR BTN yang ditawarkan PT. Bank Tabungan Negara Tbk. Cabang Padang. Untuk mengetahui jumlah nasabah KPR BTN pada PT. Bank Tabungan Negara Tbk. Cabang Padang dikemukakan pada tabel 1.1.

Tabel 1.1.

Jumlah Nasabah KPR BTN

Pada PT. Bank Tabungan Negara Tbk. Cabang Padang Tahun 2008-2012

\begin{tabular}{|c|c|c|c|}
\hline \multirow{2}{*}{ Tahun } & \multirow{2}{*}{$\begin{array}{c}\text { Jumlah Nasabah KPR BTN } \\
\text { (Orang) }\end{array}$} & \multicolumn{2}{|c|}{ Perubahan } \\
\cline { 3 - 4 } & & (Orang) & $(\%)$ \\
\hline
\end{tabular}




\begin{tabular}{|l|c|c|c|}
\hline 2008 & 16.987 & - & - \\
\hline 2009 & 16.311 & -676 & $-4,0$ \\
\hline 2010 & 15.223 & -1.088 & $-6,7$ \\
\hline 2011 & 14.547 & -676 & $-4,4$ \\
\hline 2012 & 15.367 & 820 & 5,6 \\
\hline & Rata-Rata & $\mathbf{- 4 0 5}$ & $\mathbf{- 2 , 4}$ \\
\hline
\end{tabular}

Sumber : PT. Bank Tabungan Negara Tbk. Cabang Padang.

Jumlah nasabah KPR BTN pada PT. Bank Tabungan Negara Tbk. Cabang Padang dari tahun 2008 sampai dengan tahun 2012 seperti yang dikemukakan tabel 1.1. mengalami fluktuasi. Jumlah nasabah KPR BTN tahun 2008 adalah 16.987 orang, kemudian tahun 2009 sampai dengan tahun 2011 mengalami penurunan setiap tahunnya hingga menjadi 14.547 nasabah pada tahun 2011 . Tahun 2012 terjadi peningkatan jumlah nasabah menjadi 15.367 nasabah tetapi jumlah nasabah pada tahun 2012 ini tidak sebanyak jumlah nasabah pada tahun 2008 dan 2009. Selama 5 tahun terakhir yaitu dari tahun 2008 sampai dengan tahun 2012 dapat diketahui terjadi kecenderungan penurunan jumlah nasabah KPR BTN pada PT. Bank Tabungan Negara Tbk. Cabang Padang per tahunnya adalah 405 orang atau $2,4 \%$.

Untuk meningkatkan jumlah nasabah ini, maka loyalitas nasabah perlu mendapat perhatian dari PT. Bank Tabungan Negara Tbk. Cabang Padang. Hal ini dikarenakan nasabah kredit yang loyal akan terus melakukan transaksi kredit dan nasabah yang loyal akan menjadi media promosi bagi perusahaan untuk meningkatkan jumlah konsumennya karena nasabah tersebut sewaktu-waktu akan melakukan promosi kepada calon nasabah dalam bentuk word of mouth, yaitu promosi yang dilakukan oleh konsumen ketika berbicara dengan lawan bicaranya tentang keunggulan dan kemudahan serta pelayanan yang didapat konsumen ketika membeli suatu produk.

Berdasarkan uraian diatas penulis tertarik untuk meneliti pemberian kredit dan kepuasan nasabah serta pengaruhnya terhadap loyalitas nasabah KPR BTN dengan judul Pengaruh Kepuasan Nasabah Terhadap Loyalitas Nasabah KPR BTN Pada PT. Bank Tabungan Negara Tbk. Cabang Padang.

\section{Perumusan Masalah}

Dari latar belakang penelitian diatas, maka penulis merumuskan permasalahan yang diteliti, yaitu bagaimanakah pengaruh kepuasan nasabah KPR BTN terhadap loyalitas pada PT. Bank Tabungan Negara Tbk. Cabang Padang?

\section{BAB II}

\section{TINJAUAN LITERATUR DAN HIPOTESIS}

\subsection{Pengertian, Jenis Bank}

Undang-Undang No. 10 Tahun 1998 tentang Perubahan Undang-Undang 
Nomor 7 Tahun 1992 tentang Perbankan mengemukakan pengertian bank adalah badan usaha yang menghimpun dana dari masyarakat dalam bentuk simpanan dan menyalurkannyakembali kepada masyarakat dalam bentuk kredit dan/atau bentukbentuk lainnya dalam rangka meningkatkan taraf hidup rakyat banyak.

Di dalam Undang-Undang No. 10 Tahun 1998 tentang Perubahan UndangUndang Nomor 7 Tahun 1992 tentang Perbankan dikemukakan jenis-jenis bank, yaitu:

1. Bank Umum adalah bank yang melaksanakan kegiatan usaha secara konvensional dan/atau berdasarkan Prinsip Syariah yang dalam kegiatannya memberikan jasa dalam lalu lintas pembayaran.

2. Bank Perkreditan Rakyat adalah bank yang melaksanakan kegiatan usaha secara konvensional dan/atau berdasarkan Prinsip Syariah yang dalam kegiatannya tidak memberikan jasa dalam lalu lintas pembayaran.

Fungsi utama bank adalah financial intermediary yaitu menghimpun dana dari masyarakat dan menyalurkannya kembali ke masyarakat untuk berbagai tujuan.

\subsection{Kredit}

Tjoekam (1999) mengemukakan kata kredit berasal dari bahasa Latin yakni credere yang berarti percaya atau to believe atau to trust. Oleh karena itu, dasar pemikiran persetujuan pemberian kredit oleh suatu lembaga keuangan/bank kepada seseorang atau badan usaha berlandaskan kepada kepercayaan (faith).

Berdasarkan Undang-Undang Nomor 10 Tahun 1998 tentang perubahan atas UU Nomor 7 Tahun 1992 tentang Perbankan, yang dimaksud dengan kredit adalah penyediaan uang atau tagihan yang dapat dipersamakan dengan itu, berdasarkan persetujuan atau kesepakatan pinjam meminjam antara bank dengan pihak lain yang mewajibkan pihak peminjam untuk melunasi utangnya setelah jangka waktu tertentu dengan pemberian bunga.

Jenis kegiatan usaha yang bervariasi mengakibatkan bervariasi pula kebutuhan jenis kreditnya. Dalam prakteknya, pemberian fasilitas kredit oleh bank dikelompokkan ke dalam jenis yang masing-masing, dilihat dari berbagai segi. Pembagian jenis ini ditujukan untuk mencapai sasaran atau tujuan tertentu, mengingat setiap jenis usaha memiliki berbagai karakteristik tertentu.

\subsection{Kepuasan Konsumen}

Pengertian kepuasan pelanggan menurut Kotler (2005) adalah perasaan suka/tidak seseorang terhadap suatu produk setelah membandingkan kinerja produk tersebut dengan harapannya. Tjiptono (2005) mengemukakan kepuasan pelanggan adalah sikap keseluruhan terhadap suatu barang atau jasa setelah perolehan dan pemakaiannya.

Tjiptono dan Anastasia (2003) mengemukakan tujuan akhir pemasaran ialah memuaskan pelanggan. Tujuan pemasaran bukan mencari laba, tetapi memberi kepuasan. Dengan adanya kepuasan akan terjadi pembelian ulang. Berapa banyak frekuensi ulang pembelian dan berapa banyak jumlah pembelian pada akhirnya akan meningkatkan laba perusahaan. Kepuasan pelanggan mencakup perbedaan antara harapan dan kinerja atau hasil yang dirasakan.

Alma (2003) mengemukakan kepuasan adalah respon konsumen yang sudah terpenuhi keinginannya. Jika barang dan jasa yang dibeli cocok dengan apa 
yang diharapkan konsumen, maka akan terdapat kepuasan dan sebaliknya bila kenikmatan yang diperoleh konsumen melebihi harapannya maka konsumen betul-betul puas, mereka akan mengajak teman-temannya.

Tjiptono dan Anastasia (2003) mengemukakan manfaat dari adanya kepuasan pelanggan, yaitu:

1. Hubungan antara perusahaan dan para langganannya menjadi harmonis.

2. Memberikan dasar yang baik bagi pembelian ulang.

3. Dapat mendorong terciptanya loyalitas pelanggan.

4. Membentuk suatu rekomendasi dari mulut ke mulut (word of mouth) yang menguntungkan bagi perusahaan.

5. Reputasi perusahaan menjadi baik di mata langganan.

6. Laba yang diperoleh dapat meningkat.

Tjiptono dan Anastasia (2003) mengemukakan pelanggan adalah orang yang menerima hasil pekerjaan seseorang atau suatu organisasi, maka hanyamerekalah yang dapat menentukan kualitasnya seperti apa dan hanya mereka yang dapat menyampaikan apa dan bagaimana kebutuhan mereka.

\subsection{Loyalitas Konsumen}

Loyalitas pelanggan menurut Tjiptono (2005) adalah komitmen pelanggan terhadap suatu merek, toko atau pemasok berdasarkan sikap yang sangat positif dan tercermin dalam pembelian ulang yang konsisten. Selanjutnya Griffin (2003) mengemukakan loyalitas dapat didefinisikan berdasarkan perilaku membeli, nasabah yang loyal adalah orang yang melakukan pembelian berulang secara teratur, membeli antar lini produk atau jasa, mereferensikan kepada orang lain, dan menunjukkan kekebalan terhadap tarikan dari pesaing.

Karakteristik dari loyalitas menurut Alma (2003) adalah konsumen melakukan pembelian ulang secara teratur/regular, mereka memiliki persepsi mendalam tentang apa yang mau mereka beli, dimana harus membeli. Perusahaan jangan dulu berpuas hati sebab pelanggan yang ada belum tentu otomatis akan menjadi konsumen yang loyal. Mereka juga membeli produk-produk lain, bukan satu produk saja yang ditawarkan oleh produsen. Mereka merekomendasikan teman-temannya untuk juga membeli produk yang sama ke tempat yang sama dan mereka tidak mudah beralih ke produk saingan.

Di dalam dunia bisnis, menurut Alma (2003) terdapat lima tingkatan konsumen, yaitu:

1. Terrorist customer, yaitu mereka yang seperti bermusuhan dengan perusahaan karena suka mengungkapkan cerita tidak baik tentang perusahaan.

2. Transactional customer, yaitu mereka berhubungan hanya sebatas transaksi saja.

3. Relationship customer, yaitu mereka yang telah melakukan pembelian ulang.

4. Loyal customer, yaitu konsumen yang selalu setia dengan perusahaan, walaupun orang lain menceritakan keburukan perusahaan tersebut.

5. Advocator customer, inilah pelanggan istimewa dan excellent.

Alma (2003) mengemukakan tujuan marketing bukan hanya menguasai pasar, atau mempertahankan pelanggan, tapi meningkatkan peranan konsumen yang ada, ikut memperluas, meningkatkan kualitas tiap pelanggan agar mereka menjadi customer loyality. Terdapat 6 alasan mengapa perusahaan harus menjaga 
dan mempertahankan pelanggannya, yaitu:

1. Pelanggan yang sudah ada, prospeknya dalam memberi keuntungan cenderung lebih besar.

2. Biaya menjaga dan mempertahankan pelanggan yang sudah ada, jauh lebih kecil daripada biaya mencari pelanggan baru.

3. Pelanggan yang sudah percaya pada suatu lembaga dalam satu urusan bisnis, cenderung akan percaya juga dalam urusan/bisnis yang lain.

4. Jika pada suatu perusahaan banyak langganan lama, akan memperoleh keuntungan karena adanya peningkatan efisiensi. Langganan lama pasti tidak akan banyak lagi tuntutan, perusahaan cukup menjaga dan mempertahankan mereka. Untuk melayani mereka bisa digunakan karyawan-karyawan baru dalam rangka melatih mereka sehingga biaya pelayanannya lebih murah. Tentu karyawan junior ini telah diberi pengarahan terlebih dahulu agar tidak berbuat sesuatu yang mengecewakan pelanggan

5. Pelanggan lama ini tentu lebih banyak pengalaman positif berhubungan dengan perusahaan, sehingga mengurangi biaya psikologis dan sosialisasi.

6. Pelanggan lama akan selalu membela perusahaan dan berusaha juga menarik/memberi referensi teman-teman lain dan lingkungannya untuk mencoba berhubungan dengan perusahaan.

\section{Hipotesis}

Berdasarkan perumusan masalah yang telah dikemukakan, maka hipotesis penelitian adalah diduga kepuasan nasabah KPR BTN berpengaruh signifikan terhadap loyalitas pada PT. Bank Tabungan Negara, Tbk. Cabang Padang.

\section{BAB III}

\section{METODE PENELITIAN}

\subsection{Jenis Penelitian}

Jenis penelitian yang dilakukan adalah penelitian kuantitatif yaitu menguji hipotesis penelitian untuk mengetahui ada atau tidak adanya pengaruh signifikan kepuasan nasabah KPR BTN terhadap loyalitas nasabah pada PT. Bank Tabungan Negara, Tbk. Cabang Padang.

\subsection{Lokasi dan Objek Penelitian}

Lokasi penelitian di PT. Bank Tabungan Negara, Tbk. Cabang Padang yang beralamat di Jalan Rasuna Said No. 3 Padang. Objek yang diteliti adalah nasabah KPR BTN pada PT. Bank Tabungan Negara, Tbk. Cabang Padang.

\subsection{Populasi dan Sampel Penelitian}

Populasi menurut Sarwono (2009) adalah seperangkat unit analisis yang lengkap yang sedang diteliti. Populasi penelitian adalah nasabah KPR BTN pada PT. Bank Tabungan Negara, Tbk. Cabang Padang dengan berjumlah 15.367 orang pada akhir tahun 2012.

Sampel menurut Sarwono (2009) adalah sub dari seperangkat elemen yang 
dipilih untuk dipelajari. Pedoman penentuan jumlah sampel menggunakan rumus Slovin sebagai berikut:

$$
\mathrm{n}=\frac{\mathrm{N}}{1+\mathrm{N}\left(\mathrm{d}^{2}\right)}=\frac{15367}{1+15367\left(0,10^{2}\right)}=\frac{15367}{39,4}=390
$$


Dimana: $\mathrm{n}=$ Jumlah sampel.

$\mathrm{N}=$ Ukuran populasi.

$\mathrm{d}=$ Presisi yang diharapkan, yaitu $\alpha=0,05$.

Dari rumus Slovin maka jumlah sampel penelitian yang digunakan adalah 390 orang nasabah KPR BTN pada PT. Bank Tabungan Negara, Tbk. Cabang Padang. Metode sampel yang digunakan adalah teknik random yang sederhana yaitu simple random sampling.

\subsection{Definisi Operasional Variabel Penelitian}

Untuk mengetahui definisi operasional dari masing-masing variabel penelitian dikemukakan pada tabel 3.1.

Tabel 3.1.

Definisi Operasional Variabel Penelitian

\begin{tabular}{|c|c|c|}
\hline Variabel & Konsep Variabel & Indikator \\
\hline $\begin{array}{l}\text { Kepuasan } \\
\text { Nasabah } \\
\text { KPR } \\
\text { BTN }\end{array}$ & $\begin{array}{l}\text { Kepuasan adalah tingkat perasaan } \\
\text { seseorang setelah mebandingkan } \\
\text { harapan dengan kinerja atau hasil } \\
\text { yang dirasakan (Supranto, 2001). }\end{array}$ & $\begin{array}{l}\text { 1. Kualitas produk. } \\
\text { 2. Kualitas pelayanan. } \\
\text { 3. Emosional. } \\
\text { 4. Harga. } \\
\text { 5. Biaya. } \\
\text { (Lupiyoadi, 2001). }\end{array}$ \\
\hline $\begin{array}{l}\text { Loyalitas } \\
\text { Nasabah } \\
\text { KPR } \\
\text { BTN }\end{array}$ & $\begin{array}{l}\text { Loyalitas adalah orang yang } \\
\text { melakukan pembelian berulang } \\
\text { secara teratur, membeli antar lini } \\
\text { produk atau jasa, mereferensikan } \\
\text { kepada orang lain, dan } \\
\text { menunjukkan kekebalan terhadap } \\
\text { tarikan dari pesaing (Griffin, } \\
\text { 2003). }\end{array}$ & $\begin{array}{l}\text { 1. Pembelian berulang secara } \\
\text { teratur. } \\
\text { 2. Membeli antar lini produk atau } \\
\text { jasa. } \\
\text { 3. Mereferensikan kepada orang } \\
\text { lain } \\
\text { 4. Kekebalan terhadap tarikan dari } \\
\text { pesaing. } \\
\text { (Griffin, 2003). }\end{array}$ \\
\hline
\end{tabular}

Untuk penganalisaan data maka jawaban angket penelitian untuk setiap variabel penelitian menggunakan skala likert, yaitu setiap butir pertanyaan variabel penelitian diberi skor nilai atau bobot yang disusun secara bertingkat seperti yang dikemukakan pada tabel 3.2.

Tabel 3.2.

Skala Likert Kuisioner Variabel Penelitian

\begin{tabular}{|l|c|c|}
\hline Bentuk Jawaban & Simbol & Bobot / Skor \\
\hline Sangat Setuju & SS & 5 \\
\hline Setuju & S & 4 \\
\hline Cukup Setuju & CS & 3 \\
\hline Tidak Setuju & TS & 2 \\
\hline Sangat Tidak Setuju & STS & 1 \\
\hline
\end{tabular}




\subsection{Jenis dan Sumber Data}

Dalam kenyataannya menurut Sugiarto (2003) jenis data yang dikumpulkan terdiri dari:

1. Data primer, merupakan data yang didapat dari sumber pertama, baik individu atau perseorangan seperti hasil wawancara atau hasil pengisian kuesioner yang biasa dilakukan oleh peneliti.

2. Data sekunder sering disebut metode penggunaan bahan dokumen, karena dalam hal ini peneliti tidak secara langsung mengambil data sendiri tetapi meneliti dan memanfaatkan data atau dokumen yang dihasilkan pihak-pihak lain.

Jenis dan sumber data yang digunakan dalam penelitian ini yaitu :

1. Data primer bersumber dari angket penelitian yang dijawab sampel penelitian.

2. Data sekunder bersumber dari PT. Bank Tabungan Negara, Tbk. Cabang Padang, buku-buku, literatur-literatur dan jurnal penelitian.

\subsection{Teknik Pengumpulan Data}

Pengumpulan data dilakukan dengan cara:

1. Kuisioner.

2. Studi kepustakaan.

\subsection{Teknik Analisis Data}

Teknik analisis data yang digunakan meliputi uji validitas, uji reliabilitas, analisis regresi, analisis koefisien korelasi, analisis koefisien determinasi, dan uji t. Untuk penganalisaan data dari setiap teknik analisis data yang digunakan maka digunakan program SPSS (Statistical Program For Social Science).

\subsubsection{Uji Validitas}

Uji validitas menurut Nugroho (2005) digunakan untuk mengetahui kelayakan butir-butir dalam suatu daftar pertanyaan dalam mendefinisikan variabel. Menilai kevalidan masing-masing butir pertanyaan dapat dilihat dari nilai Corrected Item-Total Correlation. Suatu butir pernyataan dikatakan valid jika nilai dari Corrected Item-Total Correlation lebih besar dari 0,3.

\subsubsection{Uji Reliabilitas}

Uji reliabilitas (keandalan) menurut Nugroho (2005) merupakan ukuran suatu kestabilan dan konsistensi responden dalam menjawab hal yang berkaitan dengan daftar-daftar pertanyaan yang merupakan dimensi suatu variabel dan disusun dalam suatu bentuk kuisioner. Reliabilitas suatu variabel dikatakan baik jika nilai Cronbach's Alpha lebih besar dari 0,6.

\subsubsection{Analisis Persamaan Regresi Linier Sederhana}

Regresi menurut Nugroho (2005) bertujuan untuk menguji pengaruh antara satu variabel terhadap variabel lain. Variabel yang dipengaruhi disebut variabel tergantung atau dependen, sedangkan variabel yang mempengaruhi disebut variabel bebas atau variabel independen. Model persamaan regresi linier sederhana untuk melihat loyalitas nasabah pada PT. Bank Tabungan Negara, Tbk. 
Cabang Padang sebagai akibat dari pengaruh kepuasan nasabah KPR BTN adalah sebagai berikut:

$$
\mathrm{Y}=\mathrm{a}+\mathrm{bX}
$$

dimana $: \mathrm{Y}=$ Loyalitas nasabah KPR BTN.

$\mathrm{a}=$ Konstanta.

$\mathrm{b}=$ Koefisien regresi.

$\mathrm{X}=$ Kepuasan nasabah KPR BTN.

Untuk mendapatkan nilai persamaan regresi yaitu nilai a dan b maka pengolahan data dilakukan menggunakan program SPSS.

\subsubsection{Analisis Koefisien Korelasi}

Nilai koefisien korelasi menurut Nugroho (2005) merupakan nilai yang digunakan untuk mengukur kekuatan (keeratan) antar variabel. Keeratan korelasi dapat dikelompokkan sebagai berikut:

1. Nilai koefisien korelasi dari 0,00 sampai dengan 0,20 berarti korelasi memiliki keeratan sangat lemah.

2. Nilai koefisien korelasi dari 0,21 sampai dengan 0,40 berarti korelasi memiliki keeratan lemah.

3. Nilai koefisien korelasi dari 0,41 sampai dengan 0,70 berarti korelasi memiliki keeratan kuat.

4. Nilai koefisien korelasi dari 0,71 sampai dengan 0,90 berarti korelasi memiliki keeratan sangat kuat.

5. Nilai koefisien korelasi dari 0,91 sampai dengan 0,99 berarti korelasi memiliki keeratan sangat kuat sekali.

6. Nilai koefisien korelasi 1 berarti korelasi sempurna.

\subsubsection{Analisis Koefisien Determinasi}

Koefisien determinasi menurut Nugroho (2005) bertujuan untuk mengetahui seberapa besar kemampuan variabel independen menjelaskan variabel dependen. Dalam output SPSS, koefisien determinasi terletak pada tabel Model Summary dan tertulis $R$ Square.

\subsubsection{Uji t}

Uji t menurut Nugroho (2005) bertujuan untuk mengetahui besarnya pengaruh masing-masing variabel independen secara individual (parsial) terhadap variabel dependen. Hasil uji ini pada output SPSS dapat dilihat pada tabel Coefficients. Nilai dari uji t dapat dilihat dari $p$-value pada kolom Sig.

Pengujian hipotesis uji $\mathrm{t}$ adalah sebagai berikut:

1. Ho diterima dan Ha ditolak jika nilai $p$-value pada kolom sig. lebih besar dari level of significant $(\alpha)$ yang menyatakan adanya pengaruh tidak signifikan antara kepuasan nasabah KPR BTN terhadap loyalitas nasabah pada PT. Bank Tabungan Negara, Tbk. Cabang Padang.

2. Ha diterima dan Ho ditolak jika nilai p-value pada kolom sig. lebih kecil dari level of significant $(\alpha)$ yang menyatakan adanya pengaruh signifikan antara kepuasan nasabah KPR BTN terhadap loyalitas nasabah pada PT. Bank Tabungan Negara, Tbk. Cabang Padang. 


\section{BAB IV}

\section{HASIL PENELITIAN DAN PEMBAHASAN}

\subsection{Deskripsi Variabel Penelitian}

Deskripsi hasil penelitian mengenai respon sampel penelitian mengenai kepuasan nasabah KPR BTN dan loyalitas pada PT. Bank Tabungan Negara, Tbk. Cabang Padang dibagi dalam 5 kategori sebagai berikut :

1. Nilai rata-rata kuisioner dari 1,00 sampai dengan 1,79 berarti termasuk dalam kriteria sangat tidak setuju atau sangat rendah.

2. Nilai rata-rata kuisioner dari 1,80 sampai dengan 2,59 berarti termasuk dalam kriteria tidak setuju atau rendah.

3. Nilai rata-rata kuisioner dari 2,60 sampai dengan 3,39 berarti termasuk dalam kriteria cukup setuju atau cukup tinggi.

4. Nilai rata-rata kuisioner dari 3,40 sampai dengan 4,19 berarti termasuk dalam kriteria setuju atau tinggi.

5. Nilai rata-rata kuisioner dari 4,20 sampai dengan 5,00 berarti termasuk dalam kriteria sangat setuju atau sangat tinggi.

Untuk mengetahui sebaran jawaban responden penelitian terhadap 10 butir pernyataan angket kepuasan nasabah KPR BTN pada PT. Bank Tabungan Negara, Tbk. Cabang Padang dikemukakan pada tabel 4.1.

Tabel 4.1

Nilai Rata-Rata Angket Kepuasan Nasabah KPR BTN

\begin{tabular}{|c|l|c|}
\hline No. & \multicolumn{1}{|c|}{ Pernyataan } & Rata-Rata \\
\hline 1. & Prosedur KPR BTN yang diterapkan tidak mempersulit saya. & 3,82 \\
\hline 2. & Jangka waktu realisasi KPR BTN tergolong cepat. & 3,82 \\
\hline 3. & Petugas bank bersikap ramah dan sopan kepada saya. & 3,83 \\
\hline 4. & Pelayanan KPR BTN memuaskan saya. & 3,79 \\
\hline 5. & Uang muka KPR BTN adalah ringan. & 3,88 \\
\hline 6. & Biaya provisi KPR BTN adalah ringan. & 3,79 \\
\hline 7. & Beban bunga KPR BTN termasuk rendah. & 3,79 \\
\hline 8. & Biaya denda keterlambatan angsuran KPR BTN adalah ringan. & 3,76 \\
\hline 9. & Debt collector KPR BTN bersikap sopan dalam penagihan. & 3,77 \\
\hline 10. & Outlet KPR BTN dekat dengan lokasi perumahan. & 3,58 \\
\hline \multicolumn{2}{|c|}{ Nilai Rata-Rata } & $\mathbf{3 , 7 8}$ \\
\hline
\end{tabular}

Sumber : Hasil pengolahan data, 2013

Dari tabel 4.1. diketahui kepuasan nasabah KPR BTN pada PT. Bank Tabungan Negara, Tbk. Cabang Padang tertinggi adalah uang muka KPR BTN yang tergolong murah dengan nilai rata-rata 3,88 dan kepuasan nasabah KPR BTN terendah adalah outlet KPR BTN BTN yang masih dapat dikatakan belum sepenuhnya dekat dengan lokasi perumahan dengan nilai rata-rata 3,58. Secara keseluruhan kepuasan nasabah KPR BTN pada PT. Bank Tabungan Negara, Tbk. Cabang Padang dikategorikan tinggi karena nilai rata-rata butir pernyataan angket kepuasan nasabah KPR BTN adalah 3,78 yang berada di antara 3,40 sampai dengan 4,19. 
Untuk mengetahui sebaran jawaban responden terhadap 10 butir pernyataan kuisioner loyalitas nasabah KPR BTN pada PT. Bank Tabungan Negara, Tbk. Cabang Padang dikemukakan pada tabel 4.2

Tabel 4.2

Nilai Rata-Rata Angket Loyalitas Nasabah KPR BTN

\begin{tabular}{|c|l|c|}
\hline No. & \multicolumn{1}{|c|}{ Pernyataan } & Rata-Rata \\
\hline 1. & Saya tidak pernah terlambat membayar angsuran KPR BTN. & 3,76 \\
\hline 2. & Saya membayar angsuran KPR BTN tepat waktu. & 3,69 \\
\hline 3. & Saya juga menabung di bank ini. & 3,73 \\
\hline 4. & Saya juga memanfaatkan jasa perbankan lainnya di bank ini. & 3,78 \\
\hline 5. & Saya akan mereferensikan KPR BTN kepada orang lain. & 3,80 \\
\hline 6. & $\begin{array}{l}\text { Saya tidak akan terpengaruh dari promosi yang dilakukan bank } \\
\text { lainnya. }\end{array}$ & 3,78 \\
\hline 7. & $\begin{array}{l}\text { Jika saya membutuhkan kredit, maka saya akan mengutamakan } \\
\text { bank ini terlebih dahulu. }\end{array}$ & 3,62 \\
\hline 8. & $\begin{array}{l}\text { Saya tidak pernah menceritakan kelemahan KPR BTN kepada } \\
\text { orang lain. }\end{array}$ & 3,70 \\
\hline 9. & Saya memberikan data verifikasi yang benar kepada BTN. & 3,75 \\
\hline 10. & Saya tidak akan mengalihkan KPR BTN kepada bank lainnya. & 3,72 \\
\hline \multicolumn{2}{|c|}{ Nilai Rata-Rata } & $\mathbf{3 , 7 3}$ \\
\hline
\end{tabular}

Sumber : Hasil pengolahan data, 2013

Dari tabel 4.2 diketahui loyalitas nasabah KPR BTN pada PT. Bank Tabungan Negara, Tbk. Cabang Padang tertinggi adalah nasabah akan mereferensikan KPR BTN kepada orang lain dengan nilai rata-rata 3,80 dan loyalitas nasabah KPR BTN terendah adalah mengutamakan PT. Bank Tabungan Negara, Tbk. terlebih dahulu jika membutuhkan kredit dengan nilai rata-rata 3,62. Secara keseluruhan loyalitas nasabah KPR BTN pada PT. Bank Tabungan Negara, Tbk. Cabang Padang dikategorikan tinggi karena nilai rata-rata butir pernyataan untuk angket loyalitas nasabah KPR BTN adalah 3,73 yang berada di antara 3,40 sampai dengan 4,19.

\subsubsection{Analisis Data}

Penganalisaan data untuk mengetahui pengaruh kepuasan nasabah KPR BTN terhadap loyalitas pada PT. Bank Tabungan Negara Tbk. Cabang Padang dilakukan dengan melakukan uji validitas, uji reliabilitas, persamaan regresi, koefisien korelasi, koefisien determinasi dan uji t.

\subsubsection{Uji Validitas}

Hasil uji validitas angket kepuasan nasabah KPR BTN pada PT. Bank Tabungan Negara Tbk. Cabang Padang yang terdiri dari 10 butir pernyataan dikemukakan pada tabel 4.3 


\section{Hasil Uji Validitas Angket Kepuasan Nasabah KPR BTN}

\begin{tabular}{|c|l|c|c|}
\hline No. & \multicolumn{1}{|c|}{ Pertanyaan } & $\begin{array}{c}\text { Corrected Item- } \\
\text { Total Correlation }\end{array}$ & Keterangan \\
\hline 1. & $\begin{array}{l}\text { Prosedur KPR BTN yang diterapkan tidak } \\
\text { mempersulit saya. }\end{array}$ & 0,654 & Valid \\
\hline 2. & $\begin{array}{l}\text { Jangka waktu realisasi KPR BTN } \\
\text { tergolong cepat. }\end{array}$ & 0,681 & Valid \\
\hline 3. & $\begin{array}{l}\text { Petugas bank bersikap ramah dan sopan } \\
\text { kepada saya. }\end{array}$ & 0,667 & Valid \\
\hline 4. & Pelayanan KPR BTN memuaskan saya. & 0,723 & Valid \\
\hline 5. & Uang muka KPR BTN adalah ringan. & 0,684 & Valid \\
\hline 6. & Biaya provisi KPR BTN adalah ringan. & 0,682 & Valid \\
\hline 7. & Beban bunga KPR BTN termasuk rendah. & 0,663 & Valid \\
\hline 8. & $\begin{array}{l}\text { Biaya denda keterlambatan angsuran KPR } \\
\text { BTN adalah ringan. }\end{array}$ & 0,641 & Valid \\
\hline 9. & $\begin{array}{l}\text { Debt collector KPR BTN bersikap sopan } \\
\text { dalam penagihan. }\end{array}$ & 0,604 & Valid \\
\hline 10. & $\begin{array}{l}\text { Outlet KPR BTN dekat dengan lokasi } \\
\text { perumahan. }\end{array}$ & 0,031 & Tidak Valid \\
\hline
\end{tabular}

Sumber : Hasil pengolahan data, 2013

Dari tabel 4.3. diketahui dari 10 butir pernyataan angket kepuasan nasabah KPR BTN pada pada PT. Bank Tabungan Negara Tbk. Cabang Padang menghasilkan 1 butir pernyataan yang dinyatakan tidak valid yaitu pernyataan nomor 10 karena nilai Corrected Item-Total Correlation tidak melebihi 0,3 sehingga tidak dapat digunakan untuk penelitian lebih lanjut. Kemudian untuk 9 butir pernyataan lainnya dinyatakan valid karena nilai Corrected Item-Total Correlation melebihi 0,3.

Hasil uji validitas angket loyalitas nasabah KPR BTN pada PT. Bank Tabungan Negara Tbk. Cabang Padang yang terdiri dari 10 butir pernyataan dikemukakan pada tabel 4.4.

Tabel 4.4.

Hasil Uji Validitas Angket Loyalitas Nasabah KPR BTN

\begin{tabular}{|c|l|c|c|}
\hline No. & \multicolumn{1}{|c|}{ Pertanyaan } & $\begin{array}{c}\text { Corrected Item- } \\
\text { Total Correlation }\end{array}$ & Keterangan \\
\hline 1. & $\begin{array}{l}\text { Saya tidak pernah terlambat membayar } \\
\text { angsuran KPR BTN. }\end{array}$ & 0,629 & Valid \\
\hline 2. & $\begin{array}{l}\text { Saya membayar angsuran KPR BTN tepat } \\
\text { waktu. }\end{array}$ & 0,640 & Valid \\
\hline 3. & Saya juga menabung di bank ini. & $-0,020$ & Tidak Valid \\
\hline 4. & $\begin{array}{l}\text { Saya juga memanfaatkan jasa perbankan } \\
\text { lainnya di bank ini. }\end{array}$ & 0,671 & Valid \\
\hline
\end{tabular}




\begin{tabular}{|c|l|c|c|}
\hline 5. & $\begin{array}{l}\text { Saya akan mereferensikan KPR BTN } \\
\text { kepada orang lain. }\end{array}$ & 0,662 & Valid \\
\hline 6. & $\begin{array}{l}\text { Saya tidak akan terpengaruh dari promosi } \\
\text { yang dilakukan bank lainnya. }\end{array}$ & 0,680 & Valid \\
\hline 7. & $\begin{array}{l}\text { Jika saya membutuhkan kredit, maka saya } \\
\text { akan mengutamakan bank ini terlebih } \\
\text { dahulu. }\end{array}$ & 0,046 & Tidak Valid \\
\hline 8. & $\begin{array}{l}\text { Saya tidak pernah menceritakan } \\
\text { kelemahan KPR BTN kepada orang lain. }\end{array}$ & 0,649 & Valid \\
\hline 9. & $\begin{array}{l}\text { Saya memberikan data verifikasi yang } \\
\text { benar kepada BTN. }\end{array}$ & 0,693 & Valid \\
\hline 10. & $\begin{array}{l}\text { Saya tidak akan mengalihkan KPR BTN } \\
\text { kepada bank lainnya. }\end{array}$ & 0,671 & Valid \\
\hline
\end{tabular}

Sumber : Hasil pengolahan data, 2013

Dari tabel 4.4. diketahui dari 10 butir pernyataan angket loyalitas nasabah KPR BTN pada pada PT. Bank Tabungan Negara Tbk. Cabang Padang menghasilkan 2 butir pernyataan yang dinyatakan tidak valid yaitu pernyataan nomor 3 dan 7 karena nilai Corrected Item-Total Correlation tidak melebihi 0,3 sehingga tidak dapat digunakan untuk penelitian lebih lanjut. Kemudian untuk 8 butir pernyataan lainnya dinyatakan valid karena nilai Corrected Item-Total Correlation melebihi 0,3.

\subsubsection{Uji Reliabilitas}

Hasil pengujian reliabilitas angket kepuasan nasabah dan loyalitas nasabah KPR BTN pada PT. Bank Tabungan Negara, Tbk. Cabang Padang adalah seperti yang dikemukakan pada tabel 4.5 .

Tabel 4.5.

Hasil Uji Reliabilitas

Angket Kepuasan dan Loyalitas Nasabah KPR BTN

\begin{tabular}{|c|l|c|c|}
\hline No. & \multicolumn{1}{|c|}{ Variabel } & Cronbach's Alpha & Keterangan \\
\hline 1. & Kepuasan nasabah & 0,860 & Reliabel \\
\hline 2. & Loyalitas nasabah & 0,819 & Reliabel \\
\hline
\end{tabular}

Sumber : Hasil pengolahan data, 2013 .

Dari tabel 4.5. diketahui angket kepuasan nasabah dan loyalitas nasabah KPR BTN pada PT. Bank Tabungan Negara, Tbk. Cabang Padang dikatakan reliabel karena nilai Cronbach's Alpha untuk masing-masing variabel penelitian lebih dari 0,6 sehingga dapat dilanjutkan untuk penelitian selanjutnya.

\subsubsection{Persamaan Regresi Linier Sederhana}

Hasil analisa data persamaan regresi linier sederhana untuk pengaruh kepuasan nasabah KPR BTN terhadap loyalitas pada PT. Bank Tabungan Negara Tbk. Cabang Padang adalah seperti yang dikemukakan pada tabel 4.6 
Tabel 4.6.

Hasil Persamaan Regresi

\begin{tabular}{|c|l|c|}
\hline No. & \multicolumn{1}{|c|}{ Keterangan } & Nilai \\
\hline 1. & Konstanta & 0,350 \\
\hline 2. & Koefisien Regresi Kepuasan nasabah & 0,893 \\
\hline
\end{tabular}

Sumber : Hasil pengolahan data, 2013 berikut :

Dari tabel 4.6. dapat dikemukakan bentuk persamaan regresi sebagai

$$
\mathrm{Y}=0,350+0,893 \mathrm{X}
$$

Maksud dari persamaan regresi tersebut adalah :

1. Nilai konstanta adalah bernilai positif yaitu 0,350 . Hal ini berarti jika kepuasan nasabah KPR BTN tidak mengalami perubahan atau nilai X adalah 0 (nol), maka loyalitas nasabah KPR BTN pada PT. Bank Tabungan Negara Tbk. Cabang Padang adalah 0,350 satuan.

2. Koefisien regresi kepuasan nasabah adalah bernilai positif yaitu 0,893 . Hal ini berarti setiap peningkatan kepuasan nasabah KPR BTN sebesar 1 satuan, maka peningkatan loyalitas nasabah KPR BTN pada PT. Bank Tabungan Negara Tbk. Cabang Padang adalah 0,893 satuan dengan asumsi variabel selain kepuasan nasabah KPR BTN adalah tetap atau tidak mengalami perubahan.

\subsubsection{Koefisien Korelasi}

Analisis koefisien korelasi kepuasan nasabah KPR BTN terhadap loyalitas pada PT. Bank Tabungan Negara Tbk. Cabang Padang dilakukan dengan menggunakan program SPSS dengan bentuk ouput SPSS seperti yang dikemukakan pada tabel 4.7

Tabel 4.7.

\section{Hasil Koefisien Korelasi}

\begin{tabular}{|c|c|}
\hline Keterangan & Nilai \\
\hline Koefisien Korelasi (R) & 0,855 \\
\hline
\end{tabular}

Sumber : Hasil pengolahan data, 2013

Berdasarkan tabel 4.7. diketahui nilai koefisien korelasi 0,855 berarti terdapat korelasi yang sangat kuat antara kepuasan nasabah KPR BTN terhadap loyalitas pada PT. Bank Tabungan Negara Tbk. Cabang Padang karena nilai koefisien korelasi yang dihasilkan lebih dari 0,71 sampai dengan 0,90.

\subsubsection{Koefisien Determinasi}

Hasil analisa data untuk koefisien determinasi adalah seperti yang dikemukakan pada tabel 4.8. 


\section{Hasil Koefisien Determinasi}

\begin{tabular}{|c|c|}
\hline Keterangan & Nilai \\
\hline Koefisien Determinasi (R Square) & 0,732 \\
\hline
\end{tabular}

Sumber : Hasil pengolahan data, 2013.

Dari tabel 4.8. dapat diketahui nilai koefisien determinasi adalah 0,732. Hal ini menunjukkan besarnya pengaruh kepuasan nasabah KPR BTN terhadap loyalitas pada PT. Bank Tabungan Negara Tbk. Cabang Padang adalah 73,2\% dan sisanya 26,8\% menunjukkan besarnya pengaruh dari selain kepuasan nasabah KPR BTN. Misalnya pengaruh dari kualitas pelayanan, citra perusahaan, kepercayaan konsumen, dan lain-lain.

\subsubsection{Uji t}

Hasil uji t dari pengaruh kepuasan nasabah KPR BTN terhadap loyalitas pada PT. Bank Tabungan Negara Tbk. Cabang Padang adalah seperti yang dikemukakan pada tabel 4.9

Tabel 4.9

Hasil Uji t

\begin{tabular}{|c|c|c|c|}
\hline Variabel & Sig. & Level of Significant & Keterangan \\
\hline Kepuasan nasabah & 0,000 & 0,05 & Signifikan \\
\hline
\end{tabular}

Sumber : Hasil pengolahan data, 2013

Dari tabel 4.9. dapat dikemukakan kepuasan nasabah KPR BTN berpengaruh signifikan terhadap loyalitas pada PT. Bank Tabungan Negara Tbk. Cabang Padang karena nilai signifikan dari variabel kepuasan nasabah 0,000 lebih kecil dari level of significant 0,05 .

\subsection{Pembahasan}

Penelitian yang telah dilakukan dengan menggunakan sampel sebanyak 390 orang yang merupakan nasabah KPR BTN pada PT. Bank Tabungan Negara, Tbk. Cabang Padang. Penelitian yang dilakukan menghasilkan yaitu kepuasan nasabah KPR BTN berpengaruh signifikan terhadap loyalitas pada PT. Bank Tabungan Negara Tbk. Cabang Padang. Hal ini dikarenakan dari uji t dihasilkan nilai signifikan kepuasan nasabah 0,000 lebih kecil dari level of significant 0,05.

Hasil penelitian yang dilakukan ini memperkuat hasil penelitian terdahulu yang dilakukan Hutomo (2009) dan Sumarjono (2013) yang menghasilkan kepuasan berpengaruh signifikan terhadap loyalitas. Dari penelitian terdahulu dan dikaitkan dengan hasil penelitian yang penulis lakukan, maka dapat disimpulkan pengujian hipotesis dari penelitian ini diterima yaitu Ha diterima dan Ho ditolak untuk menyatakan kepuasan nasabah KPR BTN mempunyai pengaruh signifikan terhadap loyalitas pada PT. Bank Tabungan Negara Tbk. Cabang Padang meningkatkan

Jika faktor-faktor yang mempengaruhi kepuasan nasabah KPR BTN ini diperhatikan maka akan dapat meningkatkan loyalitas pada PT. Bank Tabungan 
Negara Tbk. Cabang Padang. Hal ini sesuai dengan yang dikemukakan Tjiptono dan Anastasia (2003) yang mengemukakan manfaat dari adanya pelanggan diantaranya adalah dapat mendorong terciptanya loyalitas pelanggan.

Untuk itu, PT. Bank Tabungan Negara Tbk. Cabang Padang harus meningkatkan faktor-faktor yang dapat memberikan kepuasan nasabah KPR BTN terutama dalam hal uang muka KPR BTN yang tergolong ringan, sikap ramah dan sopan petugas bank kepada nasabah, prosedur KPR BTN yang diterapkan tidak mempersulit nasabah dan jangka waktu realisasi KPR BTN tergolong cepat. Selain itu, juga perlu dilakukan usaha-usaha untuk memperbaiki faktor-faktor yang belum sepenuhnya dapat memberikan kepuasan bagi nasabah KPR BTN, terutama dalam hal outlet KPR BTN yang dekat dengan lokasi perumahan, biaya denda keterlambatan angsuran KPR BTN yang memberikan keringanan bagi nasabah serta sikap sopan debt collector KPR BTN yang bersikap sopan kepada nasabah.

Sehingga dengan adanya usaha-usaha yang dilakukan PT. Bank Tabungan Negara Tbk. Cabang Padang dalam meningkatkan kepuasan nasabah KPR BTN, maka loyalitas nasabah akan semakin meningkat yaitu sikap nasabah untuk mereferensikan KPR BTN kepada orang lain, nasabah tidak terpengaruh promosi yang dilakukan bank lainnya, dan nasabah memanfaatkan jasa perbankan lainnya yang terdapat di PT. Bank Tabungan Negara Tbk. Cabang Padang.

\section{DAFTAR PUSTAKA}

Alma, Buchari. 2003. Pemasaran Strategik Jasa Pendidikan. Bandung: CV. Alfabeta.

Astiko dan Sunardi. 2002. Pengantar Manajemen Perkreditan. Yogyakarta: Andi.

Griffin, Jill. 2003. Costumer Loyalty: Menumbuhkan dan Mempertahankan Kesetiaan Pelanggan. Jakarta: Erlangga.

Hutomo, Agyl Satrio. 2009. Pengaruh Kualitas Produk Dan Tingkat Kepuasan Konsumen Terhadap Loyalitas Pelanggan Pada Produk Makanan Tela Krezz Cabang Bekasi. http://www.gunadarma.ac.id

Kotler, Philip. 2005. Manajemen Pemasaran. Jakarta: PT. Indeks Kelompok Gramedia.

Lupiyoadi, Rambat. 2001. Manajemen Pemasaran Jasa, Teori dan Praktek. Edisi Pertama. Jakarta: Salemba Empat.

Nugroho, Bhuono Agung. 2005. Strategi Jitu Memilih Metode Statistik Penelitian dengan SPSS. Yogyakarta: Andi. 
Sarwono, Jonathan. 2009. Panduan Lengkap Untuk Belajar Komputasi Statistik Menggunakan SPSS 16. Yogyakarta: CV. Andi Offset.

Sugiarto. 2003. Teknik Sampling. Jakarta : PT. Gramedia Pustaka Utama.

Sumarjono, Angga. 2013. Pengaruh Pemberian KUR dan Kepuasan Nasabah KUR Terhadap Loyalitas Pada PT. Bank Mandiri, Tbk. Business Banking Centre Cabang Padang. Padang: Universitas Tamansiswa.

Supranto, Johanes. 2001. Pengukuran Tingkat Kepuasan Pelanggan. Cetakan Kedua. Jakarta: Rineka Cipta.

Susilo, Y. Sri. 2002. Bank dan Lembaga Keuangan Lain. Jakarta: Salemba Empat.

Tjiptono, Fandi. 2005. Pemasaran Jasa. Malang: Bayumedia.

Tjiptono, Fandi dan Anastasia Diana. 2003. Total Quality Management. Edisi Revisi. Yogyakarta: CV. Andi Offset.

Tjoekam, Moh. H. 1999. Perkreditan Bisnis Inti Bank Komersial, Konsep, Tehnik dan Kasus. Jakarta: PT. Gramedia Pustaka Utama.

Undang-Undang No. 10 Tahun 1998 tentang Perubahan Undang-Undang Nomor 7 Tahun 1992 tentang Perbankan.

Yuliati, Erni. 2011. Analisis Pemberian Kredit Usaha Kecil Terhadap Perkembangan Usaha Pedagang Kecil Pada BPR Syariah Al-Washliyah Medan. Skripsi Jurusan Manajemen Fakultas Ekonomi Universitas Sumatera Utara. http://repository.usu.ac.id 